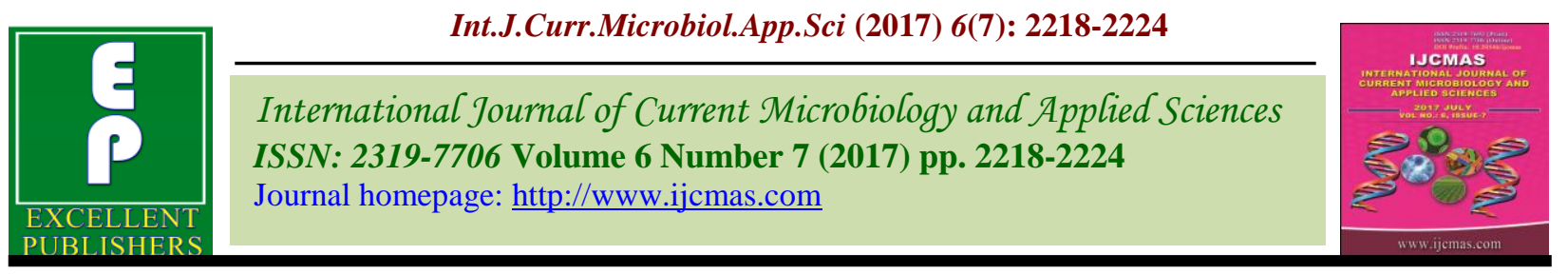

Original Research Article

https://doi.org/10.20546/ijcmas.2017.607.260

\title{
Impact of Altitudes on Soil Characteristics in Dry Deciduous Forest Ecosystem, Western Ghats, Tamil Nadu, India
}

\author{
N. Kanagaraj ${ }^{1 *}$, R.K. Kaleeswari ${ }^{2}$ and M. Tilak ${ }^{3}$ \\ ${ }^{1}$ Forest College and Research Institute, Mettupalayam, Tamil Nadu, India \\ ${ }^{2}$ Soil Science and Agricultural Chemistry, ${ }^{3}$ Agricultural Microbiology, Forest College and \\ Research Institute, Mettupalayam, Tamil Nadu, India \\ *Corresponding author
}

\section{A B S T R A C T}

A study was carried out to investigate the impact of altitude in soil physical

Keywords

Altitude, Dry deciduous forest,

Soil pH, EC,

Organic carbon.

Article Info

Accepted:

21 June 2017

Available Online:

10 July 2017 and chemical properties in dry deciduous forest of Western Ghats of Tamil Nadu. Totally fifteen soil sample were collected from altitude of $416 \mathrm{~m}$ to $965 \mathrm{~m}$. Soil physical and chemical properties such as $\mathrm{pH}, \mathrm{EC}$, Bulk density, organic carbon and water soluble carbon were studied with respect to altitude of the soil. The soil physio-chemical and biological properties of collected samples showed significant correlation with the elevation gradient. The results revealed that soil $\mathrm{pH}$, organic carbon and water soluble carbon were positively correlated with altitude, it increases as altitude increases with the rate of correlation coefficient of $0.75,0.92$ and 0.87 respectively. Soil EC and bulk density had significant correlation with elevation, it decreases with the increase in altitude with the rate of correlation coefficient -0.97 and -0.82 respectively.

\section{Introduction}

Soil is a complex system where in living soil organisms belonging to different taxonomic groups interact at different levels within the community and plays a significant role in maintenance of soil properties ${ }^{1}$. Soil microorganisms constitute a source and sink for nutrients and are involved in decomposition of wood, litter and organic matter, generating organic $\mathrm{C}, \mathrm{N}$ and energy from these organic substrates ${ }^{6}$. Forest soils are enriched with enormous nutrients due to the decomposition processes of the plants litter. So the soils in mountainous region are very

well suited for the high productivity and sustainability. Altitude is often employed to study the effects of climatic variables on soil organic matter dynamics. ${ }^{5}$ Soil $\mathrm{pH}$ may also control biotic factors such as the microbial activity and biomass composition. The change in altitudinal gradients influences soil organic matter by controlling soil water balance, soil erosion, geologic deposition processes, species and biomass production of the native vegetation and cultivated plants. ${ }^{13}$ Change in other soil properties have been found to be more variable, perhaps due to differences in 
climate, crop rotation, soil type or length of time and soil has been under organic management. ${ }^{7}$ Soil Bulk Density had significant correlation and variation with elevation higher average soil bulk density was observed in the soils of lower elevation as compared to those of higher elevation. ${ }^{3}$

\section{Materials and Methods}

\section{Study area}

The Nilgiri Biosphere Reserve was the first biosphere reserve in India established in the year 1986. It is located in the Western Ghats and includes 2 of the 10 bio geographic provinces of India. Wide ranges of ecosystems and species diversity are found in this region. Thus, it was a natural choice for the premier biosphere reserve of the country.

\section{Dry deciduous forests}

The largest area of the country's forest land is occupied by dry deciduous forests. The dry season is long and most of the trees remain leafless during that season. The forest trees are not dense, 10 to $15 \mathrm{~m}$ in height, and undergrowth is abundant. The forests are dominated by Dalbergia paniculata, Terminalia chebula, Dillenia pentagyna, Pterocarpus marsupium, Diospyros melanoxylon, Anogeissus latifolia, Boswellia serrata, Chloroxylon swietenia, Bauhinia tomentosa, Hardwickia binata, Gyrocarpus jacquini, Zizyphus glabrata, Moringa tinctoria, Dendrocalamus strictus.

\section{Collection of Soil samples}

Totally fifteen soil samples were collected in different altitude of dry deciduous forest at the depth of $15 \mathrm{~cm}$ from the soil surface. The soil samples were air dried in shade for a week and packed in air tight plastic bags. Another portion of soils are kept under $0^{\circ}$ - $20^{\circ} \mathrm{C}$ for the microbial analysis. The physical and chemical and biological properties were analyzed by following standard procedure as listed in table 2.

\section{Statistical analysis}

Soil samples collected at different altitudes in dry deciduous forest were analyzed. Results were analyzed using analysis of variance. The correlation was performed with SPSS software for Windows. The regression analysis was carried out by using MaxStat software.

\section{Results and Discussion}

Altitude is one of the main factors which directly or indirectly affect the soil characteristics. The altitude determines the micro-climate of a site. The present study projects the variations in soil properties with respect to altitude of dry deciduous forest ecosystem. (Table 3)

The important physical factor of the soil is $\mathrm{pH}$, which determines the acidity and alkalinity of the soil. In the present study acidity was observed in the soil from the altitude of $416 \mathrm{~m}$ to $965 \mathrm{~m}$ with increasing altitude it turns acid soil to slight alkali. The maximum soil $\mathrm{pH}$ (7.80) was observed in the altitude of $945 \mathrm{~m}$. The $\mathrm{pH}$ value of $6.4,6.0$, $5.42,4.57$ and 4.32 in the altitude of $300 \mathrm{~m}$, $500 \mathrm{~m}, 900 \mathrm{~m}, 1100 \mathrm{~m}$ respectively. It showed that decrease of $\mathrm{pH}$ with increasing altitude at subtropical rainforest of Lamington National Park, Australia ${ }^{12}$. The high EC content (2.25 $\mathrm{dsm}^{-1}$ ) was observed in altitude of $416 \mathrm{~m}$. The results showed that as elevation increases, decrease EC content of the soil observed. The bulk density of the soil reflects the level of compaction and amount of pore space in the soil. There is no significant difference between the bulk densities of the soil in tropical dry deciduous forest. ${ }^{4}$ There was no 
significant change observed in bulk density value with varying altitude. The high organic carbon (37.60 $\mathrm{g} \mathrm{kg}^{-1}$ ) was observed in the altitude range of $965 \mathrm{~m}$. Organic carbon (2.60 $\mathrm{g} \mathrm{kg}^{-1}$ ) was found to be low in the altitude of $416 \mathrm{~m}$.

The correlation coefficient of soil physiochemical properties studied with respect to elevation is presented in the table 4 .

The results showed that soil EC (-0.97) and Bulk density (-0.72) exhibited negative correlation with altitude of the soil in tropical dry deciduous forest. The bulk density was negatively correlated to the altitude it decreases as altitude increases with the rate of correlation coefficient -0.999 . Soil $\mathrm{pH}(0.75)$, organic carbon (0.92) water soluble carbon (0.87) showed positive correlation coefficient with altitude ${ }^{10}$. Over all altitude had significantly influenced the all five soil properties in the study area. The altitude significantly influenced the organic carbon content of the fallow land. Maximum content of organic carbon was recorded at 5500-6000 feet of height. Higher amount of organic carbon was observed at higher altitudes compared to lower altitudes ${ }^{8}$. The soil organic carbon stock at different elevation was studied and the highest Soil organic carbon stock was observed at Gosainkunda ${ }^{4}(4404 \mathrm{~m})$. Increase in the SOC is due to the change in the climatic condition at higher elevation as well the decrease in $\mathrm{OM}$ accumulation along the elevation gradients.

Table.1 Geo referenced location of soil sample at dry deciduous forest ecosystem

\begin{tabular}{|c|c|c|c|}
\hline Soil Sample & Latitude & Longitude & Mean sea level (M) \\
\hline 1 & $\mathrm{~N} 11^{0} 20^{\prime} 25.1^{\prime \prime}$ & E $076^{0} 56^{\prime} 10.1^{\prime \prime}$ & 416 \\
\hline 2 & $\mathrm{~N} 11^{0} 20^{\prime} 31.5^{\prime \prime}$ & E $076^{0} 56^{\prime} 05.0 "$ & 455 \\
\hline 3 & $\mathrm{~N} 11^{0} 20^{\prime} 41.4^{\prime \prime}$ & E $076^{0} 56^{\prime} 00.2^{\prime \prime}$ & 568 \\
\hline 4 & $\mathrm{~N} 11^{0} 20^{\prime} 44.7^{\prime \prime}$ & E $076^{0} 55^{\prime} 59.5^{\prime \prime}$ & 597 \\
\hline 5 & $\mathrm{~N} 11^{0} 20^{\prime} 47.0^{\prime \prime}$ & E $076^{0} 56^{\prime} 01.8^{\prime \prime}$ & 625 \\
\hline 6 & $\mathrm{~N} 11^{0} 20^{\prime} 54.5^{\prime \prime}$ & E $076^{0} 55^{\prime} 56.4^{\prime \prime}$ & 710 \\
\hline 7 & $\mathrm{~N} 11^{0} 20^{\prime} 58.0^{\prime \prime}$ & E $076^{0} 55^{\prime} 54.4^{\prime \prime}$ & 748 \\
\hline 8 & $\mathrm{~N} 11^{0} 21^{\prime} 00.9^{\prime \prime}$ & E $076^{0} 55^{\prime} 52.3^{\prime \prime}$ & 781 \\
\hline 9 & $\mathrm{~N} 11^{0} 21^{\prime} 06.5^{\prime \prime}$ & E $076^{0} 55^{\prime} 50.0 "$ & 826 \\
\hline 10 & $\mathrm{~N} 11^{0} 21^{\prime} 09.8^{\prime \prime}$ & E $076^{0} 55^{\prime} 49.8^{\prime \prime}$ & 842 \\
\hline 11 & $\mathrm{~N} 11^{0} 21^{\prime} 13.6^{\prime \prime}$ & E $076^{0} 55^{\prime} 50.3^{\prime \prime}$ & 856 \\
\hline 12 & $\mathrm{~N} 11^{0} 21^{\prime} 17.1^{\prime \prime}$ & E $076^{0} 55^{\prime} 57.31^{\prime \prime}$ & 869 \\
\hline 13 & $\mathrm{~N} 11^{\circ} 21^{\prime} 19.7^{\prime \prime}$ & E $076^{0} 55^{\prime} 53.2 "$ & 919 \\
\hline 14 & $\mathrm{~N} 11^{0} 21^{\prime} 23.4^{\prime \prime}$ & E $076^{0} 55^{\prime} 53.1^{\prime \prime}$ & 945 \\
\hline 15 & $\mathrm{~N} 11^{0} 21^{\prime} 23.9^{\prime \prime}$ & E $076^{0} 55^{\prime} 54.4 "$ & 965 \\
\hline
\end{tabular}

Table.2 Analytical methods for soil samples

\begin{tabular}{|l|l|l|}
\hline S.No & \multicolumn{1}{|c|}{ Parameter } & \multicolumn{1}{c|}{ Methodology } \\
\hline 1. & Soil $\mathrm{pH}$ & $\mathrm{pH} \mathrm{meter}$ \\
\hline 2. & Electrical Conductivity (EC) & Electrical Conductivity meter \\
\hline 3. & Bulk density & Core sampler method \\
\hline 4. & Organic carbon & Chromic acid wet digestion method $^{14}$ \\
\hline 5. & Water soluble carbon & Chromic acid wet digestion \\
\hline
\end{tabular}


Table.3 Physico-chemical and biological properties of soil in tropical dry deciduous forest

\begin{tabular}{|c|c|c|c|c|c|}
\hline $\begin{array}{c}\text { Soil } \\
\text { Sample No. }\end{array}$ & pH & $\begin{array}{c}\mathrm{EC} \\
\left(\mathrm{dSm}^{-1}\right)\end{array}$ & $\begin{array}{c}\text { Bulk } \\
\text { density } \\
\left(\mathrm{Mg} \mathrm{m}^{-3}\right)\end{array}$ & $\begin{array}{l}\text { Organic } \\
\text { carbon } \\
\left(\mathrm{g} \mathrm{kg}^{-1}\right)\end{array}$ & $\begin{array}{c}\text { Water } \\
\text { Soluble carbon } \\
\left(\mathrm{g} \mathrm{kg}^{-1}\right)\end{array}$ \\
\hline 1 & 5.90 & 2.25 & 1.37 & 2.60 & 0.12 \\
\hline 2 & 5.95 & 2.17 & 1.33 & 4.90 & 0.14 \\
\hline 3 & 5.76 & 1.89 & 1.53 & 6.60 & 0.18 \\
\hline 4 & 5.87 & 1.80 & 1.25 & 13.60 & 0.25 \\
\hline 5 & 5.90 & 1.40 & 1.33 & 7.80 & 0.29 \\
\hline 6 & 6.40 & 1.21 & 1.21 & 11.80 & 0.19 \\
\hline 7 & 5.90 & 1.03 & 1.17 & 13.60 & 0.26 \\
\hline 8 & 5.60 & 1.34 & 1.37 & 14.40 & 0.26 \\
\hline 9 & 6.22 & 1.02 & 1.29 & 15.00 & 0.28 \\
\hline 10 & 6.30 & 1.17 & 1.08 & 21.70 & 0.27 \\
\hline 11 & 6.80 & 0.95 & 1.14 & 23.80 & 0.24 \\
\hline 12 & 7.30 & 1.02 & 1.21 & 24.10 & 0.31 \\
\hline 13 & 7.56 & 0.87 & 1.17 & 28.00 & 0.32 \\
\hline 14 & 7.80 & 0.80 & 1.17 & 31.30 & 0.33 \\
\hline 15 & 7.42 & 0.58 & 1.05 & 37.60 & 0.36 \\
\hline Mean & 6.45 & 1.30 & 1.24 & 17.12 & 0.25 \\
\hline
\end{tabular}

Table.4 Correlation coefficient of physio-chemical and biological properties of soils with elevation

\begin{tabular}{|l|c|c|c|c|c|c|}
\hline & Altitude & $\mathrm{pH}$ & $\mathrm{EC}$ & $\begin{array}{c}\text { Bulk } \\
\text { Density }\end{array}$ & $\begin{array}{c}\text { Organic } \\
\text { Carbon }\end{array}$ & $\begin{array}{c}\text { Water Soluble } \\
\text { Carbon }\end{array}$ \\
\hline Altitude & 1 & & & & & \\
\hline $\mathrm{pH}$ & 0.75 & 1.00 & & & & \\
\hline $\mathrm{EC}$ & -0.97 & -0.71 & 1.00 & & & \\
\hline Bulk density & -0.72 & -0.65 & 0.74 & 1.00 & & \\
\hline Organic carbon & 0.92 & 0.87 & -0.86 & -0.78 & 1.00 & \\
\hline Water soluble carbon & 0.87 & 0.66 & -0.87 & -0.61 & 0.84 & 1 \\
\hline
\end{tabular}

Fig.1 Linear regression line between altitude and soil pH of dry deciduous forest

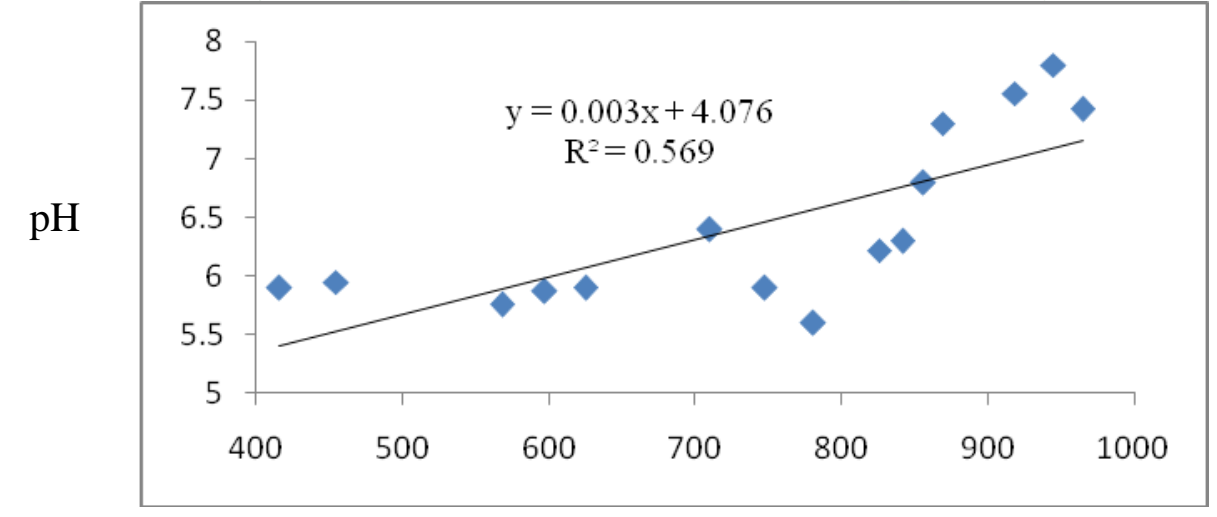

Altitude (m) 
Fig.2 Linear regression line between altitude and soil EC of dry deciduous forest

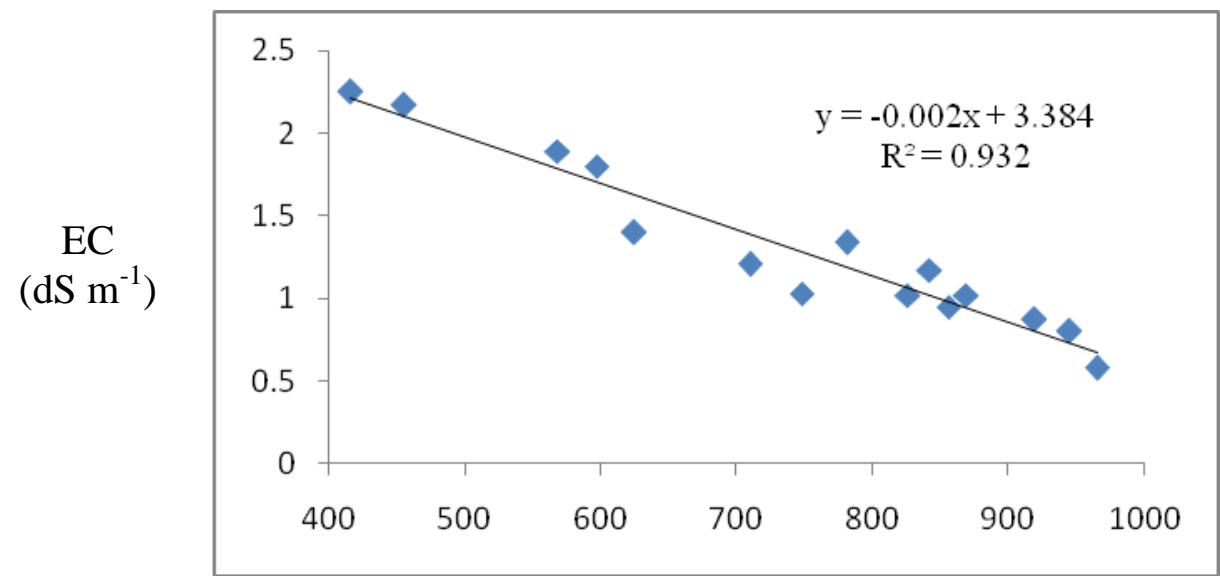

Altitude (m)

Fig.3 Linear regression line between altitude and soil bulk density of dry deciduous forest

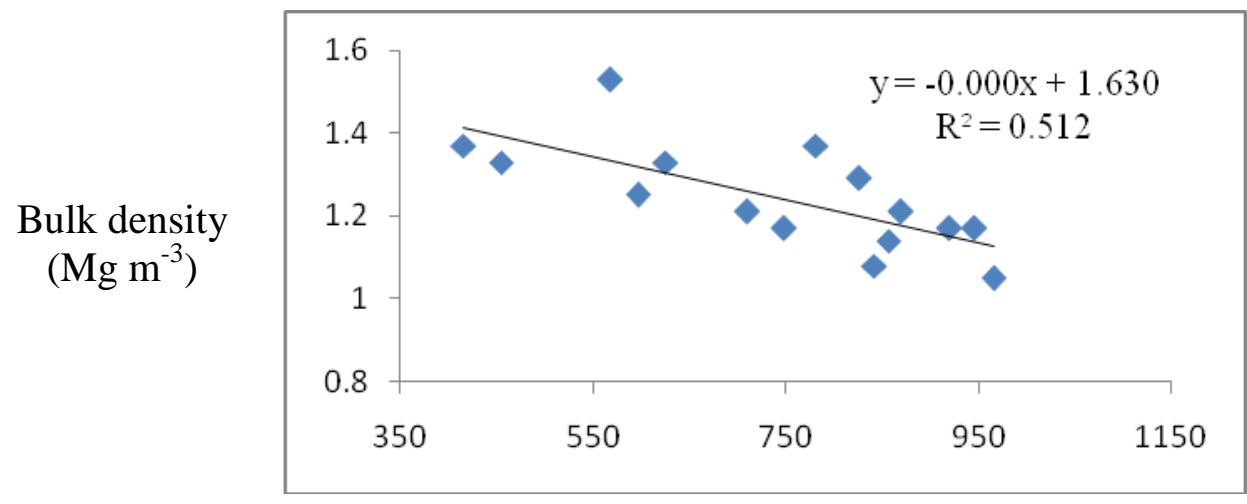

Altitude (m)

Fig.4 Linear regression line between altitude and soil organic carbon of dry deciduous forest

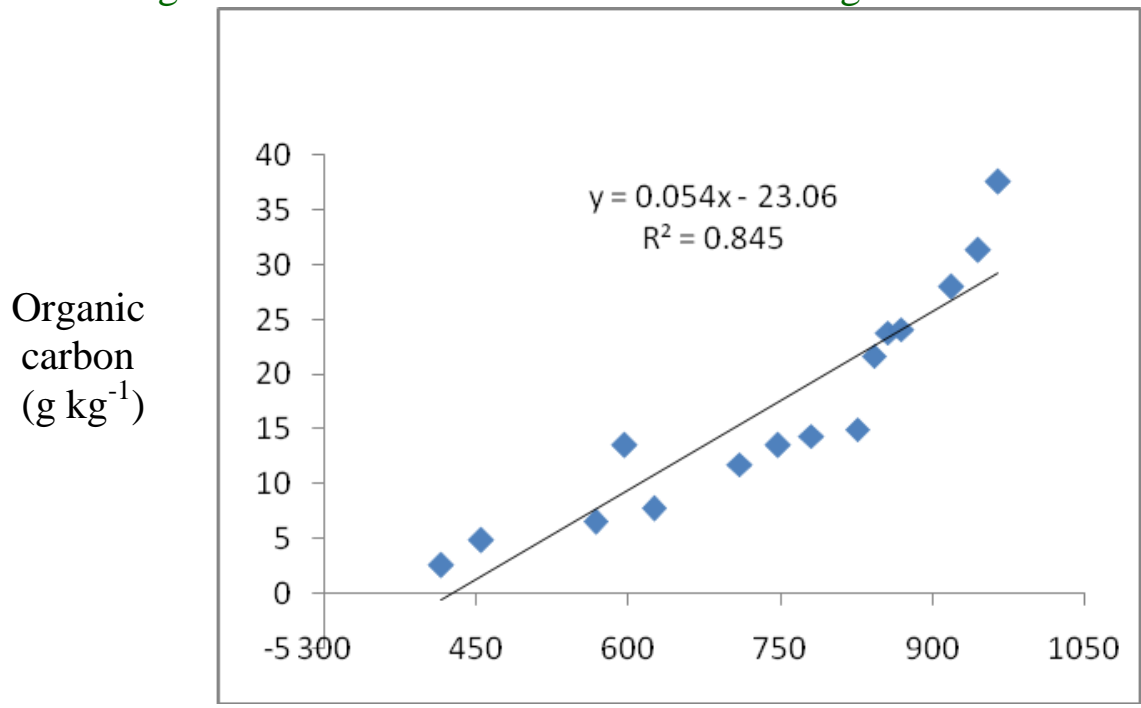

Altitude (m) 
Fig.5 Linear regression line between altitude and soil water soluble carbon of

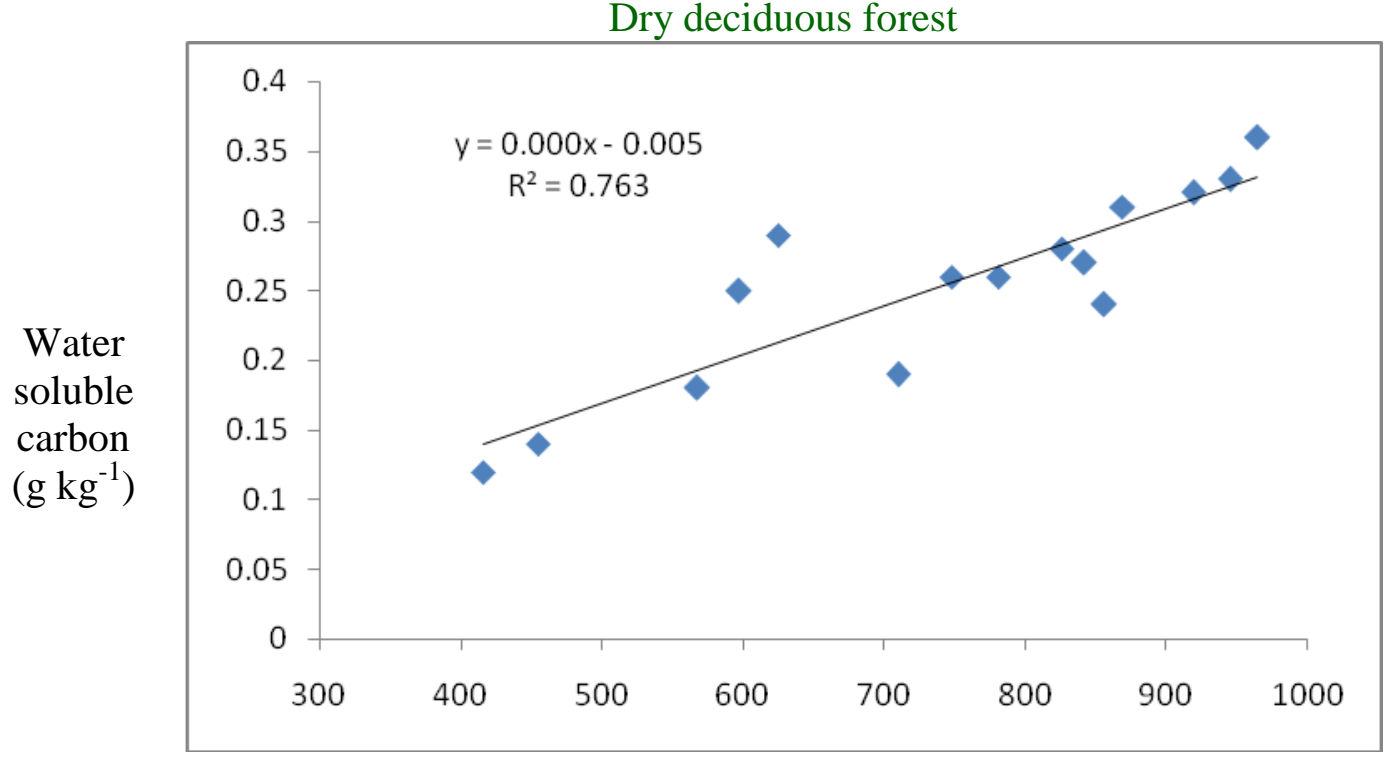

Altitude (m)

Regression line and equation of soil properties with reference to altitude were presented in figures $1,2,3,4$ and 5 . The observation from the regression line of altitude with soil $\mathrm{pH}$, Organic carbon and water soluble carbon showed the positive correlation (Figures 1,4 and 5) which indicate the attainable $\mathrm{pH}$, Organic carbon and water soluble carbon were 4.07, 23.06, 0.005 respectively and increase of $\mathrm{pH} 0.003$ for every unit increase in altitude. Regression equation of altitude with EC and bilk density showed negative regression line (Figures 2 and 3) which indicates, attainable EC and Bulk density were 3.38 and 1.63. Every unit of increases in altitude with decreasing rate of EC as 0.002 .

In conclusion, the present study showed that changes in altitude had significant impact on soil $\mathrm{pH}, \mathrm{EC}$, bulk density, organic carbon, in which $\mathrm{pH}(0.75)$, organic carbon (0.92), water soluble carbon (0.87) showed positive correlation coefficient with altitude of the soil. Soil EC (-0.97) and bulk density (0.72) showed negative correlation coefficient with altitude of the forest in the tropical dry deciduous forest. This study paves an away to understand the effect of changes in soil property effects on plant phytochemistry and its biodiversity of plants of the area.

\section{Acknowledgement}

I am very grateful to the Rajiv Gandhi National Fellowship funded by University Grants Commission for supporting this research as part of my Ph.D. program.

\section{References}

1. Garbeva P., Van Veen J.A. and Van Elsas J.D. (2004); Microbial diversity in soil: selection microbial populations by plant and soil type and implications for disease suppressiveness. Annual review of phytopathology, 42:243-270.

2. Gupta and C.Dakshinamoorthi. 1980. Procedures for Physical Analysis of Soil and Collection of Agrometeorological Data. Indian Agricultural Research Institute, New Delhi, 293p.

3. Kidanemariam.A, H. Gebrekidan, T. Mamo, K. Kibret. 2012. Impact of 
Altitude and Land Use Type on Some Physical and Chemical Properties of Acidic Soils in Tsegede Highlands, Northern Ethiopia. Open Journal of Soil Science, 2: 223-233.

4. Lekhendra T, Dipesh R, Prakriti S, Ranjan A and Ram SS (2015) Carbon sequestration Potential and Chemical Characteristics of Soil along an Elevation transect in Southern Himalayas, Nepal, International Research Journal of Environment Sciences, Vol. 4(3), 28-34.

5. Lemenih M, and F. Itanna, "Soil Carbon Stocks and Turnovers in Various Vegetation Type and Arable Lands along an Elevation Gradient in Southern Ethiopia," Ge-oderma, Vol. 123, No. 12, 2004, pp. 177-188.

6. Lindahl B.D., Ihrmark K., Boberg J., Trumbore S.E., Högberg P., Stenlid J. and Finlay R.D. (2007); Spatial separation of litter decomposition and mycorrhizal nitrogen uptake in a boreal forest. The New phytologist, 173(3):611-620.

7. Lockeretz.W, G. Sheares and D.H. Kohl. Organic farming in the corn belt, Science (Washington DC) 211: 540547. 1981.

8. Mauryaa.B.R., Vimal Singha, P. P. Dhyanib and Sunanyana Kashyap (2014) Impact Of Altitudes On Soil Characteristics And Enzymatic Activities In Forest And Fallow Lands Of Almora District Of Central
Himalaya, Oct. Jour. Env. Res. Vol. 2(1): 1-9.

9. Richards, L.A. 1954. Diagnosis and Improvement of Saline and Alkali Soils. U.S. Salinity Laboratory, U.S. Dept. Agric. Hbk. 60, pp. 160.

10. Saeed S, Muhammad Younus Khan Barozai, Alia Ahmad, Syed Haider Shah. 2014. Impact of Altitude on Soil Physical and Chemical Properties in Sra Ghurgai (Takatu mountain range) Quetta, Balochistan, International Journal of Scientific \& Engineering Research, Volume 5, Issue 3

11. Schofield, R.K. and Taylor, A.W. 1955. The measurement of soil $\mathrm{pH}$. Soil Sci. Soc. Proc. 19: 164-167.

12. Strong, C.L., Boulter, S.L., Laidlaw, M.J., Maunsell, S.C., Putland, D. and Kitching, R.L. 2011. The physical environment of an altitudinal gradient in the rainforest of Lamington National Park, southeast Queensland. Memoirs of the Queensland Museum - Nature 55(2): 251-270.

13. Tan Z.X, R. Lal, N. E. Smeck and F. G. Calhoun, 2004. "Rela-tionships between Surface Soil Organic Carbon Pool and Site Variables," Geoderma, Vol. 121, No. 3-4, pp. 185-187.

14. Walkley A, and I.A. Black. 1934. An examination of the Degtjareff method for determining soil organic matter, and a proposed modification of the chromic acid titration method. Soil Science, 37:29-38.

\section{How to cite this article:}

Kanagaraj, N., R.K. Kaleeswari and Tilak, M. 2017. Impact of Altitudes on Soil Characteristics in Dry Deciduous Forest Ecosystem, Western Ghats, Tamil Nadu, India. Int.J.Curr.Microbiol.App.Sci. 6(7): 2218-2224. doi: https://doi.org/10.20546/ijcmas.2017.607.260 